\title{
Grand Challenges in Weed Management
}

\author{
Bhagirath Singh Chauhan* \\ The Centre for Crop Science, Queensland Alliance for Agriculture and Food Innovation, The University of Queensland, \\ Gatton, QLD, Australia
}

Keywords: weed management, weed science, crop competition, herbicide, integrated weed management (IWM)

\section{OPEN ACCESS}

Edited and reviewed by:

Singarayer Kumardas Florentine, Federation University, Australia

*Correspondence:

Bhagirath Singh Chauhan b.chauhan@uq.edu.au

Specialty section:

This article was submitted to Weed Management, a section of the journal Frontiers in Agronomy

Received: 12 November 2019 Accepted: 18 December 2019 Published: 22 January 2020

Citation:

Chauhan BS (2020) Grand Challenges in Weed Management.

Front. Agron. 1:3

doi: 10.3389/fagro.2019.00003
The current global population of 7.7 billion is expected to reach over 9 billion by 2050 . To feed this population, world food production will need to be increased by 70 to $100 \%$ (www.fao.org). There are several biotic and abiotic constraints to crop production, in addition to socioeconomic and crop management related issues (Ghersa, 2013). Weeds are the most important biotic constraints to agricultural production in both developing and developed countries. In general, weeds present the highest potential yield loss to crops along with pathogens (fungi, bacteria, etc.) and animal pests (insects, rodents, nematodes, mites, birds, etc.) which are of less concern (Oerke, 2006). Weeds compete with crops for sunlight, water, nutrients, and space. In addition, they harbor insects and pathogens, which attack crop plants. Furthermore, they destroy native habitats, threatening native plants and animals.

Yield losses in crops due to weeds depend on several factors such as weed emergence time, weed density, type of weeds, and crops, etc. Left uncontrolled, weeds can result in 100\% yield loss. In Australia, the overall cost of weeds to Australian grain growers has been estimated at AUD 3.3 billion annually (Llewellyn et al., 2016). In terms of yield losses, weeds amounted to 2.7 million tons of grain at a national level. In India, these costs were much higher. Weeds cost Indian agricultural production over USD 11 billion each year (Gharde et al., 2018). In the same study, yield losses due to weeds were estimated at $36 \%$ in peanut (Arachis hypogaea L.), $31 \%$ in soybean (Glycine max (L.) Merr.), 25\% in maize (Zea mays L.), and $19 \%$ in wheat (Triticum aestivum L.). In the USA, weeds cost USD 33 billion in lost crop production annually (Pimentel et al., 2005). These studies from different economies indicate the substantial yield and economic loss caused by weeds.

The current total global grain production is $\sim 2.1$ billion metric tons. Assuming an overall yield loss of $10 \%$ due to weeds (www.fao.org/3/a0884e/a0884e.pdf), the total loss in grain production is $\sim 200$ million metric tons. If this loss can be reduced by half, grain production would increase by 100 million metric tons, which could serve in reducing hunger worldwide.

In developing countries, where farm size is small, weeds are removed manually. This practice is becoming less common as a result of the urbanization of labor migrating to cities and rising wage costs in agriculture. Hand weeding is being replaced by herbicide use. In developed countries, such as Australia and the USA, herbicides are already widely used to control weeds. However, over-reliance on herbicides with similar modes of action has resulted in the evolution of herbicideresistant weeds. At present, more than 500 unique cases of herbicide-resistant weeds have been reported globally (Heap, 2019). Out of these total cases, more than 160 are from the USA and over 90 cases are from Australia, making them the two countries with the highest number of cases of herbicide resistance. These nations are followed by Canada, China, and Brazil. The maximum number of herbicide-resistant weed species reported in different crops are in the order of: wheat $>$ maize $>$ rice (Oryza sativa L.) $>$ soybean $>$ spring barley (Hordeum vulgare L.) > canola (Brassica napus L.) > cotton (Gossypium hirsutum L.) (Heap, 2019). New herbicides with different modes of action are needed to manage herbicide-resistant weeds; however, no major mode of action has been introduced in the past three decades (Duke, 2012). These issues suggest the need to develop different weed management options, and to consider the potential for integrating them 
with herbicide use. These concerns have also encouraged weed scientists around the world to develop ecologically-based weed management tools (Chauhan and Gill, 2014).

To develop effective and sustainable weed management tactics, knowledge of weed biology and ecology is very important (Chauhan and Johnson, 2010). A recent review highlighted and prioritized current issues for weed science research (Chauhan et al., 2017). Therefore, this article discusses only selected issues and methods.

\section{WEED BIOLOGY AND ECOLOGY}

To develop any weed management program, it is essential to understand the biology and ecology of weeds. The number of studies into weed biology has increased more recently, as we still lack a basic information on a number of important species. A better understanding of the environmental factors affecting weed seed germination would help to develop effective management practices through strategies of increasing germination so that seedlings can be killed or for the purpose of suppressing germination (Chauhan and Johnson, 2010). Based on such understanding, strategies to deplete weed seed banks by influencing weed seed germination could be included in management programs (Gallandt, 2006). Similarly, information on weed phenology would allow more specific control methods to be developed by accurately estimating the timing and effects of weed competition on crop yield (Ghersa and Holt, 1995). A recent study on Amaranthus palmeri S. Watson phenology concluded that while species originating from different regions of the USA can vary biologically, it was the plant's environmental plasticity which contributed to population spread (Spaunhorst et al., 2018).

Most of the studies on weed biology and ecology have used a small number of populations; however, populations from one area may differ from those from other areas because of differential management practices, rainfall, temperature, soil type, etc. Therefore, in future studies, there is a need to include several populations in order to draw conclusions from the available data.

\section{CROP COMPETITION}

Any strategy in which a crop is used to manage weeds is considered a sustainable weed control practice. Such strategies need to be integrated with other tools to achieve effective weed management. In this technique, the effect of weeds on the crop is reduced through increasing crop competitiveness or by reducing the competitiveness of weeds (Mortensen et al., 1998; Gibson et al., 2002). Crop competitiveness can be increased by narrowing crop row spacing, increasing crop seeding rate, adjusting crop planting direction, using a weedcompetitive crop cultivar, and increasing precise application of nutrients so that they are available to crops rather than weeds. Growing a weed-competitive crop can significantly reduce weed biomass and weed seed production in-crop. Reduced seed numbers are always preferred by growers as such strategies progressively deplete weed seeds in the long run if integrated with other weed management tools (Mashingaidze et al., 2009).

Although crop competition is not a new technique, the potential for more effective use exists, particularly for herbicideresistant weeds. A single or double herbicide application would control weeds at the early stage of the crop before the traits of a competitive crop would reduce the need for future weed management 3 to 4 weeks after planting (Chauhan, 2012). The aim is to close crop canopy as soon as possible. Weeds emerging after canopy closure are less able to grow and produce biomass and seeds. Further research is needed where crop competition components are integrated with herbicide use and other weed management tools.

\section{THERMAL WEED MANAGEMENT}

Plant tissues are susceptible to high temperatures, which can disrupt physiological functions. Heat can be applied in different ways to control weeds: direct flaming (Knezevic et al., 2011), solarization (Horowitz et al., 2017), microwaves (Brodie et al., 2007), laser radiations (Mathiassen et al., 2006), steam (Rask and Kristoffersen, 2007), and electrocution (Parish, 1990). These methods of weed control can be used in fallows to kill herbicide-resistant weeds. More research is needed if these techniques are to be used in field crops.

\section{CLIMATE CHANGE}

The main outcomes associated with climate change are an increase in carbon dioxide $\left(\mathrm{CO}_{2}\right)$ concentration, temperature, and the severity and frequency of drought and flooding. Much of the research on the impact of climate change in weeds has focused on $\mathrm{CO}_{2}$, mostly conducted in the USA (Chauhan et al., 2017). There is a need to include other factors (e.g., temperature and water availability) and global regions in this research with emphasis on the mechanisms responsible for differential response to varying climatic conditions. Herbicide efficacy also stands to be affected by projected climatic conditions. For example, rising $\mathrm{CO}_{2}$ was found to increase glyphosate tolerance in a $\mathrm{C}_{3}$ weedy species, Chenopodium album L. (Ziska et al., 1999). Such changes in herbicide tolerance suggest that the efficacy of chemical weed control may be reduced in the future.

\section{MODELING AND ROBOTICS}

The application of modeling and robotics in a highly scientific and practical manner will help to achieve site-specific and economical weed management in the future (Bajwa et al., 2015; Singh et al., 2019). The development of efficient guidance systems, therefore, is a critical area of research for decisionsupport systems and site-specific weed management which may take some time, particularly in developing countries. 


\section{HERBICIDE USE}

Herbicides are an integral part of any weed control system. Current dependence on herbicides requires a more refined approach, particularly through correct application techniques, in order to extend the life of many modes of action. Use of full herbicide rates, herbicide mixtures and herbicide rotations may reduce the risk of evolution of resistance in weeds. These strategies need particular attention in developing countries. Research also needs to be conducted on the development and application of nanoherbicides in different cropping systems.

\section{INTEGRATED WEED MANAGEMENT (IWM)}

IWM is the control of weeds using different, complimentary methods within a system rather than relying on a single method. The main aim of IWM is to reduce the selection pressure for the development of resistance to any single method of weed control (Chauhan et al., 2017). Unfortunately, weed research in most countries is oriented toward herbicide research. Effective weed

\section{REFERENCES}

Bajwa, A. A., Mahajan, G., and Chauhan, B. S. (2015). Nonconventional weed management strategies for modern agriculture. Weed Sci. 63, 723-747. doi: 10.1614/WS-D-15-00064.1

Brodie, G., Hamilton, S., and Woodworth, J. (2007). An assessment of microwave soil pasteurization for killing seeds and weeds. Plant Prot. Q. 22, 143-149.

Chauhan, B. S. (2012), Weed ecology and weed management strategies for dry-seeded rice in Asia. Weed Technol. 26, 1-13. doi: 10.1614/WT-D-1100105.1

Chauhan, B. S., and Gill, G. S. (2014). "Ecologically based weed management strategies," in Recent Advances in Weed Management, eds B. S. Chauhan and G. Mahajan (New York, NY: Springer Science+Business Media), 1-11. doi: 10.1007/978-1-4939-1019-9_1

Chauhan, B. S., and Johnson, D. E. (2010). The role of seed ecology in improving weed management strategies in the tropics. Adv. Agron. 105, 221-262. doi: 10.1016/S0065-2113(10)05006-6

Chauhan, B. S., Matloob, A., Mahajan, G., Aslam, F., Florentine, S. K., and Jha, P. (2017). Emerging challenges and opportunities for education and research in weed science. Front. Plant Sci. 8:1537. doi: 10.3389/fpls.2017. 01537

Duke, S. (2012). Why have no new herbicide modes of action appeared in recent years? Pest Manage. Sci. 68, 505-512. doi: 10.1002/ps. 2333

Gallandt, E. R. (2006). How can we target the weed seedbank? Weed Sci. 54, 588-596. doi: 10.1614/WS-05-063R.1

Gharde, Y., Singh, P. K., Dubey, R. P., and Gupta, P. K. (2018). Assessment of yield and economic losses in agriculture due to weeds in India. Crop Prot. 107, 12-18. doi: 10.1016/j.cropro.2018. 01.007

Ghersa, C. M. (2013). "Agroecological basis for managing biotic constraints," in Sustainable Food Production, eds P. Christou, R. Savin, B. A. Costa-Pierce, I. Misztal, and C. B. A.Whitelaw (New York, NY: Springer), 18-30. doi: 10.1007/978-1-4614-57978_196

Ghersa, C. M., and Holt, J. S. (1995). Using phenology prediction in weed management: a review. Weed Res. 35, 461-470. doi: 10.1111/j.1365-3180.1995. tb01643.x

Gibson, K. D., Fischer, A. J., Foin, T. C., and Hill, J. E. (2002). Implications of delayed Echinochloa spp. germination and duration of competition for management and a reduced risk of the evolution of herbicideresistant weeds depends on further research into IWM across global settings.

\section{CONCLUSIONS}

Weeds are a major biotic constraint to production in different cropping systems. A single method of control will not provide adequate long-term weed management, instead often resulting in the development of resistance. Weeds are the cause of significant yield loss, even after the application of a particular control method. There is a growing necessity to reduce this yield loss in order to feed an ever-increasing human population. Therefore, there is a need to develop effective and sustainable IWM programs.

\section{AUTHOR CONTRIBUTIONS}

The author confirms being the sole contributor of this work and has approved it for publication. integrated weed management in water-seeded rice. Weed Res. 42, 351-358. doi: 10.1046/j.1365-3180.2002.00295.x

Heap, I. (2019). International Survey of Herbicide Resistant Weeds. Available online at: www.weedscience.org (accessed august 10, 2019).

Horowitz, M., Regev, Y., and Herzlinger, G. (2017). Solarization for weed control. Weed Sci. 31, 170-179. doi: 10.1017/S00431745000 68788

Knezevic, S., Datta, A., Stepanovic, S., Bruening, C., Neilson, B., and Gogos, G. (2011). Weed control with flaming and cultivation in corn. Phytopathology 101, 81-92.

Llewellyn, R. S., Ronning, D., Ouzman, J., Walker, S., Mayfield, A., and Clarke, M. (2016). Impact of Weeds on Australian Grain Production: The Cost of Weeds to Australian Grain Growers and the Adoption of Weed Management and Tillage Practices. Report for GRDC. CSIRO, 112.

Mashingaidze, A. B., van der Werf, W., Lotz, L. A. P., Chipomho, J., and Kropff, M. J. (2009). Narrow rows reduce biomass and seed production of weeds and increase maize yield. Ann. Appl. Biol. 155, 207-218. doi: 10.1111/j.1744-7348.2009. 00331.x

Mathiassen, S. K., Bak, T., Christensen, S., and Kudsk, P. (2006). The effect of laser treatment as a weed control method. Biosyst. Eng. 95, 497-505. doi: 10.1016/j.biosystemseng.2006.08.010

Mortensen, D. A., Dieleman, J. A., and Johnson, G. A. (1998). "Weed spatial variation and weed management," in Integrated Weed and Soil Management, eds J. L. Hatfield, D. D. Buhler, and B. A. Stewart (Chelsea, MI: Ann Arbor Press), 293-310.

Oerke, E. C. (2006). Crop losses to pests. J. Agric. Sci. 144, 31-43. doi: $10.1017 /$ S0021859605005708

Parish, S. (1990). A review of non-chemical weed control techniques. Biol. Agric. Hortic. 7, 117-137. doi: 10.1080/01448765.1990.97 54540

Pimentel, D., Zuniga, R., and Morrison, D. (2005). Update on the environmental and economic costs associated with alien-invasive species in the United States. Ecol. Econ. 52, 273-288. doi: 10.1016/j.ecolecon.2004. 10.002

Rask, A. M., and Kristoffersen, P. (2007). A review of non-chemical weed control on hard surfaces. Weed Res. 47, 370-380. doi: 10.1111/j.1365-3180.2007. 00579.x

Singh, V., Bagavathiannan, M., Chauhan, B. S., and Singh, S. (2019). Evaluation of current policies on the use of unmanned aerial vehicles 
in Indian agriculture. Curr. Sci. 117, 25-29. doi: 10.18520/cs/v117/i1/ 25-29

Spaunhorst, D. J., Devkota, P., Johnson, W. G., Smeda, R. J., Meyer, C. J., and Norsworthy, J. K. (2018). Phenology of five Palmer amaranth (Amaranthus palmeri) populations grown in Northern Indiana and Arkansas. Weed Sci. 66, 457-469. doi: 10.1017/wsc. 2018.12

Ziska, L. H., Teasdale, J. R., and Bunce, J. A. (1999). Future atmospheric carbon dioxide may increase tolerance to glyphosate. Weed Sci. 47, 608-615. doi: $10.1017 /$ S0043174500092341
Conflict of Interest: The author declares that the research was conducted in the absence of any commercial or financial relationships that could be construed as a potential conflict of interest.

Copyright (c) 2020 Chauhan. This is an open-access article distributed under the terms of the Creative Commons Attribution License (CC BY). The use, distribution or reproduction in other forums is permitted, provided the original author(s) and the copyright owner(s) are credited and that the original publication in this journal is cited, in accordance with accepted academic practice. No use, distribution or reproduction is permitted which does not comply with these terms. 